Зайцева О.І., Жосан Г.В.

\title{
ВПРОВАДЖЕННЯ СОЦІАЛЬНО-ЕТИЧНОГО МАРКЕТИНГУ В СИСТЕМУ АДАПТИВНОГО УПРАВЛІННЯ ПІДПРИЕМСТВАМИ В УМОВАХ УСВІДОМЛЕНОГО СПОЖИВАННЯ
}

\begin{abstract}
У статті обтрунтовано доџільність впровадження концепиії соціально-етичного маркетингу в систему адаптивного управління підприємствами в умовах усвідомленого споживання. Досліджено періодизацію становлення сочіально-етичного маркетингу на підприємствах України. Запропоновано функціональні сфери впровадження соиіально-етичного маркетингу в систему адаптивного управління підприємством і визначено критерії результативності впровадження.
\end{abstract}

Ключові слова: соціально-етичний маркетинг, конщепџія, система адаптивного управління, усвідомлене споживання.

Постановка проблеми. В умовах глобальних світових трансформацій процес прийняття управлінських рішень, окрім раціональної доцільності та економічної обгрунтованості, знаходиться під впливом соціальних, когнітивних та емоційних чинників. Економічні теорії змінюються також, набуваючи поведінських, гуманістичних та етичних якостей. Поряд 3 цим, суспільство «дорослішає», стає усвідомленим і відповідальним за наслідки власної життєдіяльності. I хоча українське бізнессередовище ще ілюструється фінансовими асиметріями, соціальною інертністю та екологічною безвідповідальністю, формується критична маса науковців та практиків, які відчувають потребу у нових концепціях управління, яким притаманне нове етичне наповнення і нові наукові підходи. В якості такої концепції, яка найбільш доцільна для впровадження в систему адаптивного управління підприємствами в означених умовах, авторами обрана концепція соціально-етичного маркетингу, що обумовило тему даної статті, їі актуальність і мету.

Аналіз останніх досліджень $\mathbf{i}$ публікацій. Концепція соціально-етичного маркетингу спрямована на адаптивне управління сучасними підприємствами у відповідності 3 очікуванням соціуму. Тому перед менеджерами та провідними фахівцями постають задачі впровадження положень міжнародних і українських стандартів соціальної відповідальності бізнесу (ISO 14000

\footnotetext{
(c) Зайцева Олена Іванівна, к.е.н., доцент, професор кафедри менеджменту та маркетингу Херсонського національного технічного університету, м. Херсон, тел.: 0664149641, email: lenzai@ukr.net

Жосан Ганна Володимирівна, к.е.н., старший викладач кафедри менеджменту та маркетингу, Херсонський національний технічний університет, м. Херсон, тел.: 0504944327, email: ennzhosan@ gmail.com
}

«Системи управління навколишнім середовищем», ISO 9000 «Управління якістю», ISO 26000:2010 «Керівництво 3 соціальної відповідальності») в практику господарювання $[1,2,3]$. Українські дослідники констатують, що в розвинутих країнах реалізація концептуальних основ соціально-етичного маркетингу є усвідомленою нормою ведення бізнесу і регламентується на законодавчому рівні, однак, розповсюдження в підприємницьких колах нашої країни позитивного досвіду ділової практики в області добросовісної конкуренції, достовірної реклами, екологічного самообмеження, маркетингових соціальних досліджень - здійснюється повільними темпами $[4,5,6,7]$. Тому автори вважають, що потенціал маркетингового управління в контексті соціальної відповідальності ще недостатньо реалізований і пропонують наукові підходи до впровадження соціально-етичного маркетингу в систему управління підприємствами.

Формулювання цілей статті. Метою статті $\epsilon$ обгрунтування необхідності впровадження концепції соціально-етичного маркетингу в систему адаптивного управління підприємствами в умовах усвідомленого споживання.

Опис основного матеріалу дослідження. Виникнення соціальної концепції в маркетингу, спрямованої на врахуванні інтересів і вимог споживачів, бізнес-партнерів i громадськості, обумовлюється поступовим підвищенням рівня усвідомленості і зрілості ринкового підприємництва. Тому вважаємо за доцільне згідно 3 напрацюваннями попередніх науковців $[5,6]$ дослідити періодизацію становлення соціальноетичного маркетингу на підприємствах України.

Перший період (1991-1999рр.) характеризується реструктуризацією та руйнацією соціальної інфраструктури підприємств у ході роздержавлення і приватизації. На даному етапі простежується відсутність чітких економічних засад державного соціального регулювання 
підприємництва, відсутність балансу між державною політикою і інтелектуально-підприємницьким досвідом, лобіювання інтересів олігархічних структур, низька соціально-економічна свідомість керівників підприємств, відсутність дієвих важелів гармонізації інтересів держави, підприємницьких кіл і громадськості. Брак масштабних проектів соціально-економічного розвитку регіонів і відновлення окремих територій, винищення природніх ресурсів призвели до того, що, суспільство починає потроху реагувати на побічні явища гонитви за прибутком: погіршення екологічного стану, недостовірну рекламу, інтервенцію закордонних виробників, незадоволеність споживачів товарами і сервісом.

Другий період (2000-2005 pp.) характеризується формуванням механізмів ринкової самоорганізації, підтримкою держави галузевих i корпоративних цілеспрямованих програм, формуванням уявлення про корпоративну соціальну відповідальність. Починає поширюватися конс'юмеризм організований рух громадськості за розширення прав та можливостей впливу споживачів на виробників та постачальників товарів, робіт, послуг.

Третій період (з 2006 р.) характеризується інституціоналізацією корпоративної філантропії, формуванням корпоративних i приватних соціальних фондів, реалізацією соціальних програм підприємствами України, зростанням попиту на послуги суспільного характеру (освіти, медицини, будівництва, транспорту, відпочинку).

Соціально-етичні зв'язки підприємства 3 оточенням стають джерелом його ринкового життєзабезпечення, продукується контент про добровільні обмеження в контексті усвідомленого споживання.

Починають формуватися і поширюватися такі нові інструменти соціально-етичного маркетингу як фандрейзинг (для некомерційних організацій) та краудфандинг (інтеграція комерційних та некомерційних проектів).

Фандрейзинг - це пошук ресурсів (грошей, людей, устаткування, інформації, часу) для реалізації проектів та / або підтримання діяльності організацій та підприємств взагалі. В маркетинговому управлінні фандрейзинг стає дієвим інструментом в пошуку потенційних донорів для задоволення потреб реалізації певних проектів відповідними ресурсами та при формуванні громадської думки на користь підтримки підприємства, зниження репутаційних ризиків та придбання авторитету.

Також дієвим інструментом стає краудфандинг - «фінансування громадою», як певної співпраці людей, які добровільно об'єднують свої гроші чи інші ресурси разом для реалізації поставлених суспільних або комерційних цілей.

Таблиця 1

Внутрішні функціональні сфери впровадження концепції соціально-етичного маркетингу*

\begin{tabular}{|c|c|}
\hline \multicolumn{2}{|c|}{ Функціональні сфери впровадження концепції соціально-етичного маркетингу } \\
\hline Внутрішнє середо & \\
\hline Персонал & Технології \\
\hline $\begin{array}{l}\text { - забезпечення прав людини, викорінення } \\
\text { примусової і дитячої праці, дискримінації під час } \\
\text { рекрутингу, влаштування і виконання службових } \\
\text { обов'язків працівників; } \\
\text { - підтримання свободи зібрань і визнання права на } \\
\text { колективні угоди працівників; } \\
\text { - забезпечення стабільної зайнятості працівників, } \\
\text { стимулювання особистісного і професійного } \\
\text { зростання, сприяння розвитку; } \\
\text { - участь працівників в прийнятті управлінських } \\
\text { рішень, формуванні стратегії підприємства, } \\
\text { впровадження і підтримка ефективних внутрішніх } \\
\text { комунікацій; } \\
\text { - соціальна захищеність працівників, «прозора» } \\
\text { заробітна плата, сучасні мотиваційні системи оплати } \\
\text { і винагород; } \\
\text { - надання можливостей відпочинку, відновлення, і } \\
\text { активного дозвілля, допомога працівникам у } \\
\text { кризових ситуаціях; беза } \\
\text { - дотримання норм безпеки і гігієни праці }\end{array}$ & 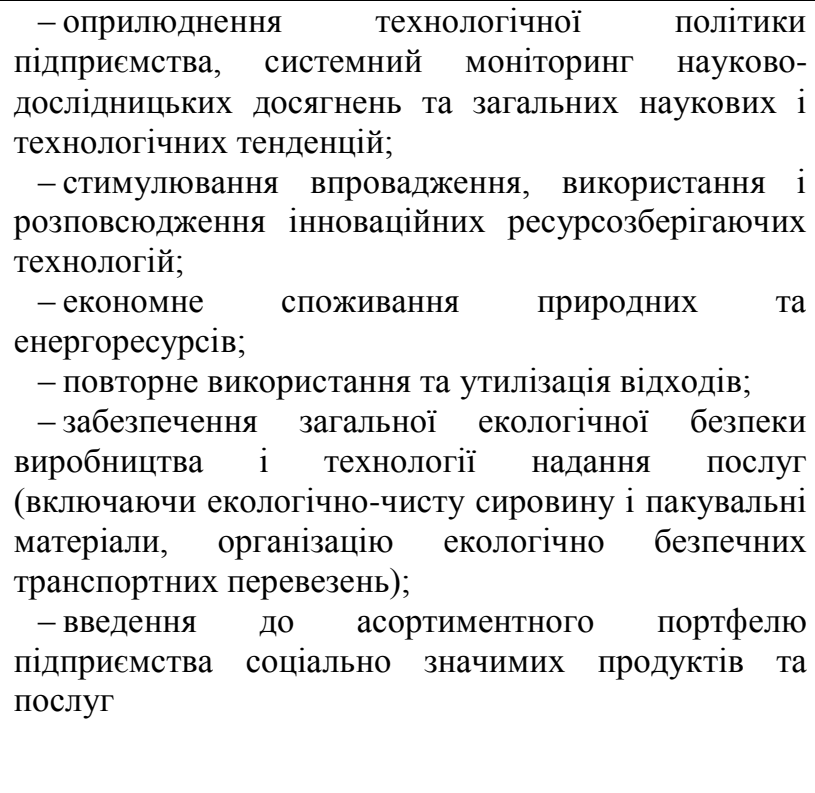 \\
\hline
\end{tabular}

*Розроблено авторами 
Громадське фінансування може виконувати різні функції: допомога постраждалим від стихійних лих, підтримка 3 боку вболівальників чи фанатів, підтримка політичних кампаній, фінансування стартапів, створення вільного програмного забезпечення тощо. Краудфандингові платформи спрямовані на розвиток культурних ініціатив та інновацій в Україні, стимулювання екологічної відповідальності, формування сильного i відкритого суспільства та реалізацію бажаних системних змін.

Таким чином, наповнене етичним змістом маркетингове управління стає нормою сучасного бізнесу. Надалі розвивається корпоративне громадянство, що припускає взаємну відповідальність бізнесу і влади перед суспільством; соціальні інвестиції, що розширюють понятя соціальної відповідальності бізнесу; перехід від добродійності до соціальних інвестицій компаній на національному i регіональному рівнях, спрямованих на вирішення найактуальніших для країни проблем у сфері зайнятості, боротьби 3 бідністю, освіти, житла, безпеки, охорони здоров'я та навколишнього середовища; закріплюється соціальне партнерство, яке передбачає перегляд сфер відповідальності бізнесу, влади i суспільства у вирішенні суспільно значущих питань.
Соціально-етичний маркетинг як відносно нова міждисциплінарна концепція наочно демонструє ефективність наукових підходів та практичних інструментів адаптації бізнесу до вимог поведінкової економіки і відіграє значну роль в спонуканні споживачів змінити свою поведінку на усвідомлену, а стратегічні кампанії адаптуватися до нових реалій, пропонуючи на ринок екологічно чисту, здорову, органічну продукцію та корисні суспільні послуги.

Впровадження концепції соціально-етичного маркетингу на підприємстві - це поступовий та багаторівневий процес. Авторами виокремлено функціональні сфери впровадження, які умовно поділено на внутрішні і зовнішні. До внутрішніх віднесено персонал i технологію виробництва/реалізації товарів, робіт, послуг. До зовнішніх віднесено споживачів, партнерів та контактні групи, навколишнє середовище і суспільство.

Після вибору сфер реалізації соціальноетичного маркетингу і прогнозування поведінки підприємств в межах визначених сфер, розробляється загальна стратегія впровадження концепції соціально-етичного маркетингу, визначаються критерії виконання та показники результативності за окремими сферами. Функціональні сфери впровадження концепції соціально-етичного маркетингу в систему адаптивного управління підприємством представлені в табл.1-3.

Таблиця 2

Зовнішні функціональні сфери впровадження концепції соціально-етичного маркетингу* Функціональні сфери впровадження концепції соціально-етичного маркетингу Зовнішнє середовище підприємства

\begin{tabular}{|c|c|}
\hline \multicolumn{2}{|c|}{ Функціональні сфери впровадження концепції соціально-етичного маркетингу } \\
\hline \multicolumn{2}{|c|}{ Зовнішнє середовище підприємства } \\
\hline Споживачі, клієнти, замовники & Партнери і контактні групи \\
\hline $\begin{array}{l}\text { - посилена відповідальність перед споживачами, } \\
\text { клієнтами, замовниками за продукцію та послуги, } \\
\text { шляхом приведення їх до найвищих стандартів } \\
\text { якості; } \\
\text { - досягнення максимізації якості й безпеки продукції } \\
\text { та послуг; } \\
\text { - встановлення коректних (обгрунтованих) цін; } \\
\text { - формування програм лояльності для постійних } \\
\text { споживачів, відкрите обговорення } 3 \text { клієнтами і } \\
\text { замовниками негативних факторів, пов’язаних } 3 \\
\text { експлуатацією виробленої продукції і отриманням } \\
\text { послуг, що надаються підприємством; } \\
\text { - відповідальність у рекламно-маркетинговому } \\
\text { просуванні за етичність і достовірність реклами }\end{array}$ & $\begin{array}{l}\text { - добросовісна ділова практика: } \\
\text { акуратність, обов’язковість у роботі } 3 \text { діловими } \\
\text { партнерами, розбудова сумлінних та взаємовигідних } \\
\text { відносин в інтересах споживачів і суспільства в } \\
\text { цілому; } \\
\text { - інформаційна відкритість для партнерів, } \\
\text { контактних груп і усіх зацікавлених сторін; } \\
\text { - прозорість закупівель сировини, обладнання, } \\
\text { вибору постачальника, відкриті тендери і конкурси; } \\
\text { - спільне розроблення стандартів якості продукції та } \\
\text { послуг; } \\
\text { - забезпечення стабільного доходу акціонерів та } \\
\text { інвесторів на довгостроковій основі; } \\
\text { - спільна участь в соціальних і екологічних проектах, } \\
\text { благодійні партнерські програми, впровадження } \\
\text { стандартів етичної ринкової поведінки, протидія } \\
\text { корупції та здирництву }\end{array}$ \\
\hline
\end{tabular}

*Розроблено авторами

Впровадження концепції соціально-етичного маркетингу в систему адаптивного управління підприємством в межах означених функціональних сфер матиме позитивні ефекти не тільки для підприємства, зміцнюючи його конкурентні позиції, а й сприятиме сталому 
розвитку регіону розташування бізнесу і громади в цілому, а критеріями результативності впровадження стануть:

-зростання вартості бізнесу і підвищення інвестиційної привабливості підприємства;

- формування позитивного іміджу, підвищення лояльності споживачів і партнерів та довіри громади до підприємства; -ефективне управління репутаційними та комерційними ризиками підприємства через зменшення невизначеності зовнішнього оточення, шляхом активного впливу на нього (якісними товарами та послугами, створенням нових робочих місць, удосконаленням екологічних процесів, благодійністю).

Зовнішні функціональні сфери впровадження концепції соціально-етичного маркетингу

\begin{tabular}{|l|l|}
\hline \multicolumn{2}{|c|}{ Функціональні сфери впровадження концепції соціально-етичного маркетингу } \\
\hline \multicolumn{2}{|c|}{ Зовнішнє середовище підприємства } \\
\hline Ринкове середовище & Суспільство \\
\hline - виконання екологічного законодавства, екологічна & - сповідання ідей соціально-етичного маркетингу, \\
відповідальність як пріоритет розвитку бізнесу; & вважати його філософією свого бізнесу, пов’язаною 3 \\
- дотримання превентивних підходів до вирішення & місією i стратегією підприємства, узгодження \\
екологічних проблем, системна оцінка впливу & досягнення стійкого розвитку підприємства і вищої \\
діяльності підприємства на навколишнє середовище; & якості життя суспільства; \\
- стимулювання розвитку і розповсюдження & - активна позиція підприємства у сфері соціально- \\
екологічно-чистих і ресурсозберігаючих технологій; & значущих проектів, врахування очікувань \\
- активна участь у проектах з охорони і відновлення & суспільства та загальноприйнятих етичних норм в \\
довкілля, ініціювання і підтримка акцій з озеленення & діловій практиці; \\
й очищення території, знешкодження виробничих та & - проведення просвітницької діяльності, взаємодія з \\
побутових відходів & місцевою громадою та владою в розвитку території \\
& розташування бізнесу та довгострокових соціальних \\
& інвестиціях; \\
\hline
\end{tabular}

*Розроблено авторами

\begin{tabular}{|c|c|c|}
\hline $\begin{array}{r}\text { Висновки } \\
\text { досліджень. }\end{array}$ & $\begin{array}{l}\text { перспективи } \\
\text { Іредставлені }\end{array}$ & $\begin{array}{r}\text { подальших } \\
\text { результати }\end{array}$ \\
\hline $\begin{array}{l}\text { дослідження мож } \\
\text { становлення науко }\end{array}$ & $\begin{array}{l}\text { уть стати під } \\
\text { ої бази, подальц }\end{array}$ & $\begin{array}{l}\text { Ітям дл } \\
\text { розвитк }\end{array}$ \\
\hline розроблення & сонкретного & равлінського \\
\hline інструментарію & впровадження & концепції \\
\hline $\mathrm{co}$ & маркетингу & систему \\
\hline
\end{tabular}

адаптивного управління підприємствами в умовах усвідомленого споживання.

Перспективами подальших наукових досліджень у даному напрямі стане визначення синергетичного ефекту від гармонійного поєднання внутрішніх та зовнішніх функціональних сфер впровадження соціально-етичного маркетингу.

\section{ПЕРЕЛІК ВИКОРИСТАНИХ ДЖЕРЕЛ}

1. Системи управління навколишнім середовищем. Склад та опис елементів і настанови щодо їх використання: ДСТУ ISO 14001-97. - К.: Держстандарт України, 1997. - С. 9-19.

2. Системи менеджменту якості. Вимоги: ДСТУ ISO 9000-2004. - К.: Держстандарт України, 2004. - С. 320.

3. Курінько Р.Н. Корпоративна соціальна відповідальність своїми ріками [Електронний ресурс] // Інтернетжурнал. - №1-2. - С. 1-28 [Цит. 2008, 15 грудня]. - Режим доступу: http://www.csrjournal.com/journal/

4. Офіційний сайт Центру розвитку корпоративної соціальної відповідальності в Україні. - [Електронний pecypc] Режим доступу: http://www.csr-ukraine.org.

5. Хамідова А. Соціально-відповідальний маркетинг як інструмент підвищення конкурентоспроможності підприємств хімічної промисловості // Маркетинг в Україні. - 2009. - №2 (54). - С. 38-40.

6. Зайцева О.І., Смець Н.В. Моделювання поведінки самоорганізованих підприємств в межах стратегічних сфер соціально-етичного маркетингу // Вісник Хмельницького Національного університету. Економічні науки. Економічні науки. - 2013, №4, Том 2(202). - С. 17-20.

7. Zhosan G. Distinctions and features of ISO 9001:2015 standard implementation in the context of social and strategic development of enterprises / O. I. Harafonova, G. V. Zhosan, R. V. Yankovoi // Науковий вісник Полісся. 2017. - № 3 (11). Ч. 2. - C. 66-71.

8. Tanklevska, N. S. Management of conscious adaptive organizations in the context of socioeconomic changes and financial turbulence / N. S. Tanklevska, Yu. Ye.Kyrylov, O. I. Zaitseva // Науковий вісник Полісся. - 2017 . № 4 (12). Ч. 1. - C. 36-39. 


\section{REFERENCES}

1. Systemy upravlinnia navkolyshnim seredovyshchem. Sklad ta opys elementiv i nastanovy shchodo yikh vykorystannia [Environmental management systems. Composition and description of elements and guidelines for their use]. (1997). DSTU ISO 14001-97. Kyiv: Derzhspozhyvstandart Ukraine [in Ukrainian].

2. Systemy menedzhmentu yakosti. Vymohy [Quality management systems. Requirements]. (2004). DSTU ISO 9000-2004. Kyiv: Derzhspozhyvstandart Ukraine [in Ukrainian].

3. Kurinko R.N. (2008). Korporatyvna sotsialna vidpovidalnist svoimy rikamy [Corporate social responsibility with its rivers]. Internet-zhurnal - Internet Journal, No. 1-2, 1-28. Retrieved from http://www.csrjournal.com/journal/ [in Ukrainian].

4. Ofitsiinyi sait Tsentru rozvytku korporatyvnoi sotsialnoi vidpovidalnosti v Ukraini [Official site of the Center for Corporate Social Responsibility Development in Ukraine]. www.csr-ukraine.org. Retrieved from http://www.csrukraine.org. [in Ukrainian].

5. Khamidova A. (2009). Sotsialno-vidpovidalnyi marketynh yak instrument pidvyshchennia konkurentospromozhnosti pidpryiemstv khimichnoi promyslovosti [Socially responsible marketing as a tool for improving the competitiveness of chemical industry enterprises]. Marketynh v Ukraini - Marketing in Ukraine, No. 2 (54), C. 38-40. [in Ukrainian].

6. Zaitseva O.I., Yemets N.V. (2013). Modeliuvannia povedinky samoorhanizovanykh pidpryiemstv v mezhakh stratehichnykh sfer sotsialno-etychnoho marketynhu [Simulation of the behavior of self-organized enterprises within the strategic spheres of social and ethical marketing]. Visnyk Khmelnytskoho Natsionalnoho universytetu. Ekonomichni nauky. Ekonomichni nauky - Bulletin of the Khmelnitsky National University. Economic sciences. Economic sciences, No. 4, Part 2(202), 17-20. [in Ukrainian].

7. Zhosan G., Harafonova O., Yankovoi R. (2017). Distinctions and features of ISO 9001:2015 standard implementation in the context of social and strategic development of enterprises. Naukovyi visnyk Polissia - Scientific bulletin Polesie, No. 3 (11), Part 2, C. 66-71.

8. Tanklevska N., Kyrylov Yu., Zaitseva O. (2017). Management of conscious adaptive organizations in the context of socioeconomic changes and financial turbulence. Naukovyi visnyk Polissia - Scientific bulletin Polesie, No. 4 (12), Part 1, 36-39.

Одержано 15.03.2018 p. 